\title{
Development of Wayang Dami Based on Local Wosdom in Story Learning in High Class
}

\author{
Anita Herlina Setianti ${ }^{1}$, Sri Utaminingsih ${ }^{2}$, Irfai Fathurrohman ${ }^{3}$ \\ \{anita.syifa.mustofa@gmail.com ${ }^{1}$, sri.utamningsih@umk.ac.id², irfai.fathurohman@umk.ac.id ${ }^{3}$ \} \\ 1,2.3Faculty of Teaching and Education, Universitas Muria Kudus \\ Gondang Manis PO. BOX 53 Bae, Kudus, Central Java, Indonesia \\ Phone (+62291) 438229, Fax (+62291)437198
}

\begin{abstract}
The purpose of this study is to describe the media needs of storytelling for pupils in primary schools, to test the village development of puppet dami media based on local wisdom of Rembang in telling students' stories in elementary schools, and to describe the effectiveness of puppet media based on local wisdom of Rembang in storytelling learners in Rembang local wisdom primary school. This research method refers to Borg and Gall's theory, using the seven steps of conducting research. The research steps are as follows: information gathering, research planning, initial product development, field testing, revision, product testing, revision of field product test results. Data collection techniques used were observation, interview, and performance story telling skills. The analysis used in this research is quantitative and qualitative analysis. Includes storytelling practices, learning observations, and validation of dami puppet media products. Analysis of Dami puppet media products based on local wisdom of Rembang includes 6 stages. The analysis technique used is the analysis of the performance of the assessment of storytelling skills, then look for the effectiveness of the performance results of the control class and the experimental class
\end{abstract}

Keywords: wayang dami, Rembang's local wisdom, storytelling skills.

\section{Introduction}

One literary appreciation that includes speaking skills is storytelling. The ability to tell is a productive language activity that aims to express the ability to speak to provide information to others. By telling stories, a person is able to tell a variety of stories, expressions of feelings in accordance with what he experienced, felt, seen, and read. Nurgiyantoro (2001: 278); Tarigan (1981: 35). Researchers held observations on Monday, May 20, 2019. From the results of observations, it is known that learning emphasizes teaching Indonesian aspects of language by ignoring literary appreciation. Literature is considered something less important, because it only benefits mental satisfaction. In the end, students will struggle to appreciate literature. One example is children having trouble when making stories. They are confused where to start writing stories. When students are asked to tell stories, their vocabulary does not develop. They also did not dare to tell a story in front of the class. The confidence of students has not yet developed.

Observation results also show that teaching techniques in storytelling that are applied are also not quite right. Learning about speaking skills especially telling stories only conveys theories, without any real form of true literary appreciation. Learning has not provided students the opportunity to see and explore their respective potential. When students only see 
the outside, they will be distressed. Though students are accomplished imitators. Then, when evaluating the practice of speaking skills, especially telling stories "Goose and Golden Eggs", the value obtained is still low. There are several aspects of the assessment of storytelling skills, namely the accuracy of the contents of the story, the accuracy of the appointment of the details of the story, the accuracy of the logic of the story, the accuracy of the meaning of the whole story, the accuracy of words, the accuracy of sentences, and fluency. A very low evaluation aspect is the accuracy of the meaning of the whole story, the accuracy of words, and the accuracy of sentences.

Learning also does not use media that attract students to focus on learning to tell stories. Even though the teacher is not an expert in storytelling. So that the atmosphere in the story has not been developed when the teacher tells a story. The teacher should use the learning media because with the learning media, the learning process will attract more attention of students, thus fostering student learning motivation so that it greatly helps the effectiveness of the learning process, and clarify the presentation of the message. Media in learning becomes an alternative to stimulate the activeness of students, skills and knowledge. (Fathurohman, 2014: 7; Hamalik, 1986; Sadiman, et al, 1990; Sudjana and Rivai, 1992: 2). In developing media, teachers must look at all aspects of the needs of students. According to Ibda, Hamidulloh (2017); Utaminingsih, et al (2019: 66) today many media are only oriented towards the fulfillment of the cognitive aspects of students. However, the affective and psychomotor aspects are ignored. The more uprooted local wisdom and conservation character in the development of media in learning. One of the innovations in attracting students' attention is to use creative and innovative media.

Still under observation at the same time, it is known that the stories used as teaching materials are also less familiar and foreign to students because they do not accommodate the local wisdom of Rembang Regency. Even though Rembang Regency has a large collection of stories and has been recorded. It would be nice if the story raised raised the local wisdom of Rembang Regency so that the students got to know more about the local wisdom of Rembang Regency more specifically the regional story. In addition to enriching students' knowledge about stories that develop in Rembang Regency, it also teaches them to love their own regional culture. Based on the presentation of problems regarding the lack of speaking skills, especially storytelling to elementary school students, researchers felt the need to develop a media of storytelling that was appropriate to the needs of students and based on local wisdom. The media of the story that the researchers chose was dami puppet media. This media is based on local wisdom in the form of a regional story in the Rembang Regency developed by $\mathrm{Mr}$. Kusaeri Y.S. The researcher chose wayang media because wayang is a cultural heritage, a work of art filled with ideals, tastes, and meanings. There is a religious meaning, rich in ethics and morals. Wayang serves as a means of lighting, education, and mass communication that is very familiar with the community (Rif'an, 2010). Finally, wayang was recognized by UNESCO on November 7, 2003, as an amazing cultural work in a beautiful and very valuable narrative story. The use of puppets as a learning medium has also been used by several researchers. (Matini, 2018; Salamah, 2012; Setian, 2018) Puppet is used in Balinese learning based on Character Education, social studies learning for independence figures, and to foster the spirit of nationalism. Researchers chose dami puppets because in Rembang District many dami were found as animal feed. Researchers want to develop dami as a learning medium.

The formulation of this research problem is How is the need for learning media to tell stories for students in elementary schools and How to design a wayang dami media development based on local wisdom in telling students in elementary school. The product produced in this research is dami puppet-based media, local wisdom is a puppet product made 
from dami by raising folklore that developed in Rembang Regency that has not been found in other regions. This product is expected to be useful for teachers and students in learning. There are 2 products produced, the original Media Wayang Dami and the animation.

\section{Literature Review and Hypothesis}

\subsection{Literature Review}

Arsjad and Mukti (1993: 23) mention that speaking skills are the ability to say sounds or sentences to express, express, convey thoughts, ideas, and feelings in order to convey messages verbally. Meanwhile, according to Tarigan (1983: 15) Speaking is interpreted as the ability to say articulation sounds or words to express, express, and convey thoughts, ideas, and feelings. According to Nurgiyantoro (1995: 276) speaking is the second language activity carried out by humans in a life of language, that is, after listening activity. Based on the sounds that are heard then humans learn to say and finally skilled at speaking. Speaking skills in this research are skills to convey ideas, thoughts, ideas verbally to others.

The form of speaking competency according to Nurgiyantoro, 2016 is as follows:

a. Talk based on the picture.

b. Speak based on excitatory sounds.

c. Speak based on visual and sound stimuli

d. Telling stories

e. Interview

f. Discuss and debate

g. Made a speech

Storytelling tasks based on any excitement depends on the teacher's task orders. This task is in an authentic assessment in the form of a task of retelling texts or stories. So the excitement used as material for storytelling can be in the form of books that have been read, various fictional stories, various travel experiences, and others. Storytelling based on the contents of the book is mostly done by teachers (Nurgiyantoro, 2016: 451). Tarigan (1981: 35) states that storytelling is one of the speaking skills that aims to provide information to others. It is said so, because storytelling is included in informative situations that want to make meanings or meanings clear. By telling stories, a person can convey a variety of stories, expressions of various feelings according to what has been experienced, felt, seen, read, and expressing the will and desire to share the experiences he gained.

(Nurgiyantoro, 2016: 541-452) As part of an authentic assessment, performance appraisal is also practically done through the making of a rubric. This rubric can be made by the teacher himself. Examples of story assessment rubrics based on stories read are:

Table 2.1 Table rubric Assessment skills Storytelling

\begin{tabular}{|c|c|c|c|c|c|c|}
\hline \multirow{2}{*}{ No } & \multirow{2}{*}{ Aspect of Performance } & \multicolumn{5}{|c|}{ Level Achievement } \\
\hline & & 1 & 2 & 3 & 4 & 5 \\
\hline 1 & Accuracy of story content & & & & & \\
\hline 2 & Accuracy in designating story details & & & & & \\
\hline 3 & Accuracy of story logic & & & & & \\
\hline 4 & The accuracy of the meaning of the whole story & & & & & \\
\hline 5 & The accuracy of the words & & & & & \\
\hline 6 & The accuracy of the sentence & & & & & \\
\hline 7 & Smoothness & & & & & \\
\hline
\end{tabular}


Meanwhile, according to Arsjad and Mukti (1988: 17), there are 2 stories of storytelling skills, namely:

a. Linguistic factors, including accuracy of speech, placement of stresses and tones, choice of words, use of sentences.

b. Non-linguistic factors, including: reasonable attitude, eye sight. Appropriate gestures and expressions, volume, fluency, and mastery of topics.

The story evaluation developed in this study uses the combined criteria of the two figures. The evaluation aspects referred to are the storyline that is delivered, fluency in storytelling, the use of Indonesian, and facial expressions.

Media according to Gagne, 1970; Brigss (1770) Sadiman (2015), media are various types of physical components used by teachers to stimulate students' thoughts, feelings, concerns, and interests in teaching and learning. According to Purnamawati and Eldarni (2001: 4), the definition of media is everything that can be used to channel messages from sender to recipient so that it can, stimulate students' thoughts, feelings, concerns and interests in such a way that the learning process occurs. While Gerlach \& Ely (Arsyad, 2000: 3), the media are human, material, or events that build conditions with functions and goals to make students able to gain knowledge, skills, attitudes or educate. From the opinions of some of the experts above, the learning media referred to in this study are all things that the teacher can use in the learning process to stimulate students' thoughts, concerns, interests, and readiness for learning. With this stimulation, students will gain knowledge, skills and good attitudes

The benefits of the media according to Sadiman (2015: 17) are as follows:

a. Clarify the presentation of the message so as not to be too verbal (in the form of written or spoken words).

b. Overcoming the limitations of space, time, and senses.

c. Varied media can overcome the passivity of students

d. Helping teachers overcome the diversity of the unique characteristics and characteristics of students

Other benefits of learning media are:

a. Laying concrete basics.

b. Enlarge student attention.

c. Lay the foundations that are important for the development of learning.

d. Provide real experience.

e. Developing regular thinking.

f. Help the growth of understanding that can help the development of language skills.

g. Providing experiences that are not easily obtained in other ways. (Hamalik, 1994: 15)

While the benefits of the media in this study are:

a. Reducing the presentation that is written.

b. Give students a real experience.

c. Support the development of students' language skills.

d. Overcoming students' passivity.

Dami puppet in this study was inspired by the existing puppet suket. Puppet suket comes from suket material. So from the definition of wayang suket above, what is meant by wayang dami in this study is a model of a shadow puppet made from dami. Dami comes from Javanese. The meaning of dami is rice stems. Researchers want to present an innovation that is different from raising the value of an item. Dami usually only as animal feed, but this is used as a learning medium. The cleaned rice stalks are then made in such a way that they become a puppet. Before making dami puppets, the researchers collected dried dami and then cleaned it. 
Dami is taken in the innermost part. To be strong, as a framework, researchers used wire as a frame for puppets. Then assembled with the order of making dami inspired puppets from wayang suket are as follows:

1) Chief

a) Take two rice stems, then both are folded in half right in the middle and the one we hold in a horizontal position, while the other one we pinch on the first grass in a vertical position, but give a little distance or give more edges to make the nose puppet.

b) Take a piece of rice, then fold in half. Then take another piece of rice, fold it in half and pinch it to the first rice stem with a little space. Pull part B and fold it forward then part A and fold it back.

c) Perform the steps above eight times, until they form as shown below.

d) Do the same thing as the previous step, next to the knot, use grass that has not been woven.

e) Perform the above steps seven times, leaving four strands.

f) braids the remaining four strands of rice stalks.

g) Then put the braids in front of the middle of the head

2) Agency

a) Make a braid four (knot braids four), for the puppet hand, then tie the two ends using a dead knot.

b) Insert the results of the braid in the middle of the remaining grass from the head part (the front and back are covered by the puppet body)

c) Take a piece of rice and store it in the front in a horizontal position.

d) Then wrap the ends of the rice stalks A and B to the back of the body.

e) Then paste the two rice stalks into the front of the hand. Then wrap it in the hands.

f) Repeat the above steps four times, until they form as shown below

3) Feet

a) Make a four braid knot for the legs as for the hands, then take a piece of rice, fold in half and pinch it on the braids. Pull part B and fold it forward then part A and fold it back.

b) Perform the steps above eight times.

c) Pinch the remaining rice stalks to the remaining rice stems from the head.

d) Grasp the topmost rice stem. Pull part B and fold it forward then part A and fold it back.

e) Finally tie everything from the legs to the bottom

When finished, the puppet is lacquered with varnish liquid. Then dried again. After drying, the puppets are ready to use.

Local wisdom is local ideas in the form of knowledge, beliefs, understanding, insight, customs, ethics, which are wise full of wisdom and are applied by local communities based on their experience in interacting with the environment. (Sartini, 2004; Tjahjono, 2000; Prijono, 2000; Keraf, 2000). Whereas local wisdom according to Sibarani (2012) is a form of original knowledge in the community that comes from the noble cultural values of the local community to regulate the order of people's lives. Wisdom according to (Ratna, 2011: 94) is a binding cement in the form of culture that already exists so that it is based on existence. Wisdom can be defined as a culture created by actors through an iterative process, through internalization and interpretation of religious and cultural teachings that are socialized in the form of norms and used as guidelines in daily life for the community. Local wisdom in this research is all ideas, ideas, behaviors, and culture that develop in the local community, are then applied in life based on experience. 
Types of Local Wisdom

According to Jim Ife in Hotibin (2013), states that local wisdom consists of six dimensions, namely:

\section{1) Local Knowledge}

Every community anywhere in the countryside and in the interior always has local knowledge related to their environment. Local knowledge related to climate change and dry and green cycles, types of fauna and flora, and geographical, demographic and sociographic conditions. This happens because the people have lived in a region for a long time and have experienced various social changes that cause them to be able to adapt to their environment. This adaptability becomes part of their local knowledge in conquering nature.

\section{2) Local Value.}

To regulate life together among the community members, each community has local rules or values which are adhered to and agreed upon by all its members. These values usually regulate the relationship between humans and humans, humans with nature and humans with their Lord. These values have dimensions of time, past, present and future mass values. This value will change according to the progress of the community.

\section{3) Local Skills.}

Survival ability of every community can be fulfilled if the community has local skills. The simplest local skills such as hunting, gathering, farming to make a home industry. These local skills are usually only sufficient and able to meet the needs of their respective families, or referred to as a sustainable economy. These local skills are also life skills (lifeskill), so these skills are highly dependent on the geographical conditions of the place where the community lives.

\section{4) Local resources.}

These local resources are generally natural resources, that is, non-renewable and renewable resources. The community will use local resources in accordance with their needs and will not exploit massively or commercially. Iuni's local resources have been allocated such as forests, gardens, water sources, agricultural land, and settlements. Ownership of local resources is usually collective.

\section{5) Local Decision Making Mechanism.}

According to traditional and cultural experts each community actually has its own local government or called tribal government. The tribe is a legal entity that rules its citizens to act as citizens. Each community has a different decision making mechanism - different. There are people who do democratically or "sit together low stand tall". There are also people who do it in stages or steps up and down stairs.

Types of local wisdom according to Hotibin (2013) are:

1. Tangible Local Wisdom

Wisdom that is tangible, includes:

a. Textual, several types of real wisdom such as value systems, procedures, special provisions poured into written records such as those found in primnbon traditional books, calendars, and prasi or written culture on palm leaf sheets.

b. Building / Architecture

c. Cultural / Traditional Heritage Objects (Artwork), for example keris, batik and others. 


\section{Intangible Local Wisdom}

Intangible local wisdom such as advice delivered verbally and hereditary which can be in the form of songs and hymns that contain traditional teaching values. Through advice or other forms of local intangible wisdom, social values are conveyed orally / verbally from generation to generation. The following are examples of local wisdom that contain Sundanese environmental ethics, namely:

a. Inhale my starch, paeh teu nyaho in prey (everything has its limits, including natural resources and the environment).

b. Kudu remembers bali geusan nadi (Humans are part of nature, must love nature, inseparable from nature).

Local wisdom is expressed in the form of wise words (philosophy) barupa of advice, proverbs, poetry, folklore (oral stories) and so on, rules, principles, norms, and rules of social and moral rules that become social systems, rites, ceremonial or traditional ceremonies and rituals, as well as habits that are seen in everyday behavior in social interaction (Haryanto, 2013: 368)

What is meant by local wisdom in this study is folklore that develops in Rembang Regency. This story is already there, then retold in a book written by Mr. Kusaeri Y.S. This book consists of those that have been published and distributed in each elementary school. This book tells about folklore from 14 Subdistricts in Rembang Regency.

Table 2.2 Table Title of Rembang Regency Folklore Book Volume 1

\begin{tabular}{|l|l|}
\hline No & \\
\hline 1 & Asal-usul Desa Sulang \\
\hline 2 & Terjadinya Desa Kenthong \\
\hline 3 & Putri Cempa \\
\hline 4 & Asal Mula Desa Tuyuhan \\
\hline 5 & Yuyu Rumpung \\
\hline 6 & Panje Sering \\
\hline 7 & Riwayat Terjadinya Desa Kaliori \\
\hline 8 & Pasar Penthungan \\
\hline 9 & Ki Sondong dan Ki Makerti \\
\hline 10 & Sunan Geseng \\
\hline 11 & Lahirnya Demang Waru \\
\hline 12 & Asal Mula Desa Jeruk \\
\hline 13 & Nyai Agung Maloka \\
\hline 14 & Dampo Awang \\
\hline 15 & Terjadinya Randumeteng \\
\hline 16 & Masjid Tiban di Tepi Sungai Babagan \\
\hline 17 & Riwayat Terjadinya Desa Pelang dan Sekitarnya \\
\hline 18 & Terjadinya Desa Dahbong \\
\hline 19 & Brandal Noyo Gimbal \\
\hline 20 & Ki Jalut Sukma Jati \\
\hline 21 & Bende Becak Sunan Bonang \\
\hline 22 & Pantangan Nama Han Bagi Orang Cina di Lasem \\
\hline 23 & Pek Cun Lomba Al;a Tionghoa \\
\hline 24 & Tempat Bersujud dan Makam Sunan Bonang \\
\hline
\end{tabular}


25 Dewi Siti Sari jati

Table 2.3 Table Title of Rembang Regency Folklore

Book Volume 2

\begin{tabular}{|l|l|}
\hline No & \multicolumn{1}{|c|}{ Judul } \\
\hline 1 & Asal Mula Kadipaten Lasem \\
\hline 2 & Asal Mula Desa Sedan \\
\hline 3 & Watu celeng \\
\hline 4 & Bende Becak Telgawah \\
\hline 5 & Asal Mula Desa Garung \\
\hline 6 & Merta Kusuma dan merti Kusuma \\
\hline 7 & Asal Mula Desa Gunem \\
\hline 8 & Masjid Agung Belitung Di Kalipang \\
\hline 9 & Kisah Ceritas Desa Lodan, Terjan, Dan Sekitarnya. \\
\hline 10 & Riwayat Terjadinya Desa Telas Dan Woro \\
\hline 11 & Sumur Turun \\
\hline 12 & Asal Mula Desa Pamotan \\
\hline 13 & Mbah Bajang Dukun Bayi \\
\hline 14 & Terjadinya Desa Brubulan Dan Desa Pasucen \\
\hline 15 & Tradisi Berangkat Menikah Naik Kuda \\
\hline 16 & Asal Usul Desa Menara \\
\hline 17 & Pantangan Menanam Kedelai, Talas, Dan Ketan Hitam \\
\hline 18 & Mengenal Asal Usul Desa Plawangan \\
\hline 19 & Terjadinya Gunung Genuk Dan Sorak \\
\hline 20 & Boro Tugel Cikal Baka; Desa Kabongan Kidul \\
\hline 21 & Kakek Lindri Dan Nyai Sulastri Sesepuh Desa Babadan \\
\hline 22 & Makam Mbah Sarah Di Sarang Meduro \\
\hline 23 & Pohon Gentiri,Kotak Ajaib Dan Asal Usul Desa Ngadem \\
\hline
\end{tabular}

\subsection{Previous Literature Preview}

From several studies that have been researchers read, there are several studies examining puppets as learning media, among others by Evi Rizki Salamah in 2012 in the title of Using Puppet Media in Social Sciences Learning Material Indonesian Prominent Figures to Improve Student Learning Outcomes of Class V Elementary Schools concluded that puppet media material Indonesian independence figures in fifth grade elementary school students can improve student learning outcomes. Zafira and Prima in a 2017 study entitled Thematic Puppet Media Development on the Beautiful Theme of My Country as a Supporting Scientific Approach to Class IV Elementary Schools. From these studies, the results obtained by the assessment of the validation of media experts and material 1 obtained a percentage of $88.23 \%$ and $87.50 \%$ of the results of the assessment by media experts and material 2 obtained a percentage of $98.50 \%$ and $98.43 \%$ results of the assessment by media experts and material 3 obtained percentage of $92.64 \%$ and 93.75 and finally the results of the assessment of expert material 4 obtained a percentage of $85.93 \%$ while the student questionnaire responses obtained a percentage of $97.43 \%$ in SD N 08 Tanjungrejo and $98.75 \%$ in SD N 03 The scaling and scientific approach questionnaire obtained a percentage of $90.38 \%$ in SD N 08 Tanjungrejo and $97.00 \%$ in SD N 03 Klaling. The conclusion is that the thematic wayang media is 
appropriate and can be used as a supporter of the scientific approach to the theme of the Beautiful State of Grade IV elementary school students. Research on the Introduction of Puppet Characters in the Ramayana Story Using Media Board Games for the Community by D.M Teddy Dwistyawan1, T. Arie Setiawan (2017) also concluded that the Ramayana folklore can provide solutions to the problems of insight and knowledge in the field of folklore in Indonesia. The culture of Ramayana folklore can be used in the wider community, not only in regions or that has a Ramayana culture. The Sang Prabu Board Game can convey the messages contained in the Sang Prabu story to students, students and the surrounding community. The King's Game Board can simulate how a leader. The Tale of Pela Gandong Board Game received a good response from students and students, to be developed by adding mission choices, and other story choices to make it even more interesting.

\subsection{Framework of Thinking}

This study begins with problems that occur in primary schools in learning speaking skills, especially storytelling. The problems include textbooks that do not accommodate the local wisdom of Rembang Regency, learning has not used suitable media, so students are not enthusiastic in learning. This causes the results of student learning in storytelling is not optimal.

From this problem, the researcher wanted to develop an interesting storytelling media and accommodate the local wisdom of Rembang Regency. Researchers make dami puppet products, then analyze the damian puppet products. After that, collecting stories that accommodate the local wisdom of Rembang Regency. After being tested, it is then applied in learning to tell stories in the high class.

For more details, illustrated in the chart below. 


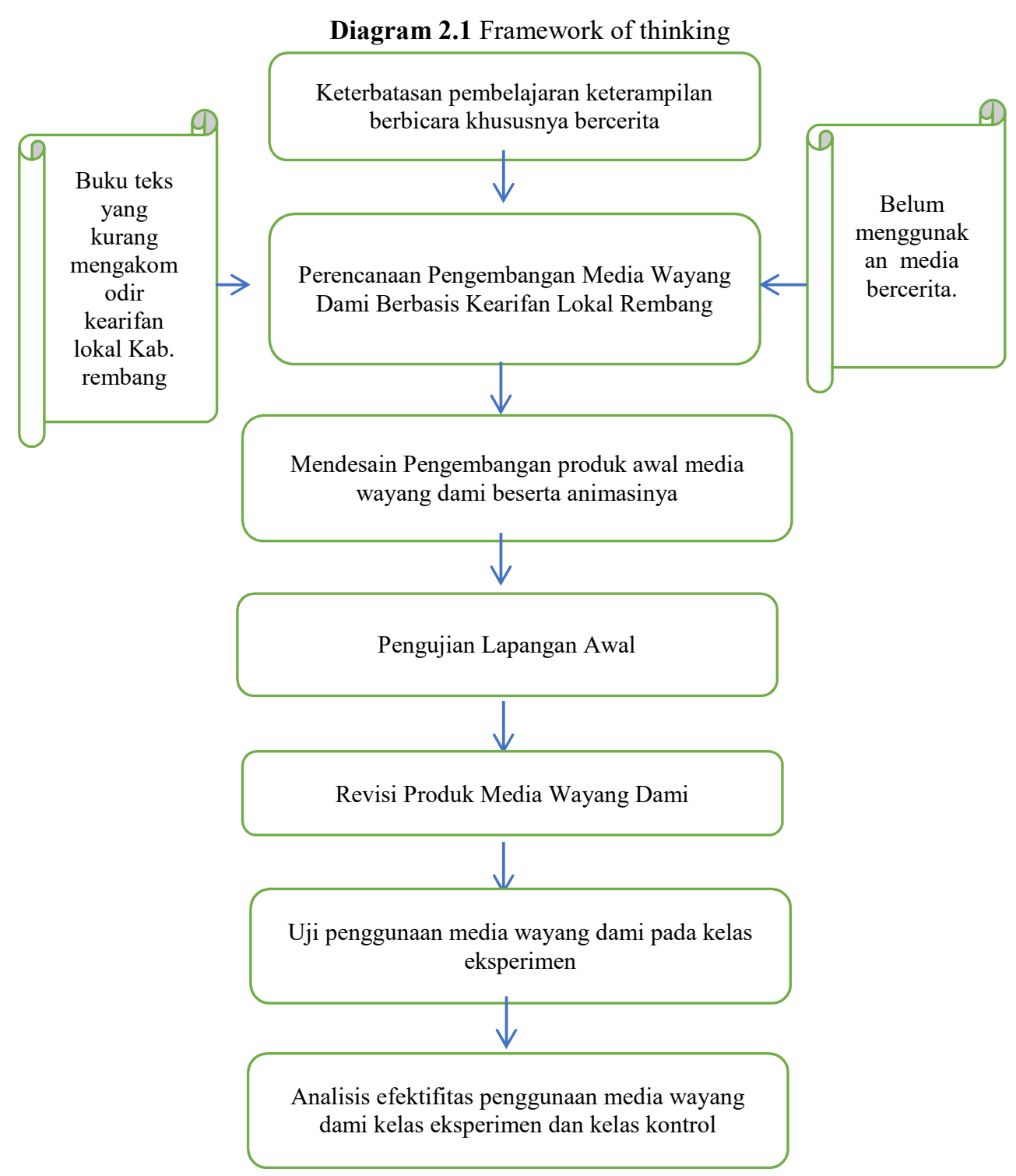

\subsection{Hypothesis}

Based on the problem and discussion of the theory, the hypothesis in this research is:

1. Development of storytelling media for students in primary schools in the form of puppets based on local wisdom in Rembang Regency to meet the needs of students.

2. The design of dami wayang media development based on local wisdom in learning to tell students in elementary school has met the criteria for media selection.

3. The development of dami wayang media based on local wisdom is effectively used as a medium in learning to tell students' stories in elementary schools 


\section{Research Methods}

\subsection{Research Desaign}

This research used research and development design with ten steps of implementation referring to Borg and Gall theory, due to time constraints, the researcher only used seven steps of research implementation. According to Borg and Gall (in Sugiyono, 2015: 34) states that Educational R \& D is based on industrial development research models, where research results are used to design new products and procedures, and subsequently are field tested systematically, evaluated, and refined until they meet the criteria the specifics are effectiveness, quality, and meet standards. This research took place in collaboration with researchers and teachers at SDN Sukorejo, Sumber District, Rembang Regency. The research will be carried out in seven stages of research. The details of the research stages are as follows:

\section{Stage I Research and Information Collection}

In this stage, the researcher will analyze needs, review literature, small-scale research related to the topic of study. To find out the needs of developing media for storytelling, it is done by conveying a questionnaire related to the needs of the media, speaking, especially speaking skills. Before the questionnaire is distributed, it is first consulted to the supervisor.

\section{Phase II Planning}

In this stage, the researcher will define the development of wayang dami based on local wisdom, formulate research objectives, determine the sequence of learning to tell stories, and test feasibility on a small scale. The sequence of storytelling learning planned is as follows:

a. The teacher introduces students to Rembang Regency folklore books. Then the teacher asks students to read some titles that they enjoy.

b. Then the teacher will tell stories using dami puppets that have been designed so that the characters match the selected story.

c. Some students try to tell a story in front of the class with the same title.

d. Provide opportunities for students to try to use puppets in storytelling.

While small-scale trials are carried out by small groups of 5 students.

Phase III Developing the initial product in the form of Dami Puppet Media and its Animation The steps taken are a. Preparing folklore material in the Rembang Regency Folk Story book. b. Making dami puppets 1) choose a nice dry dami, 2) the process of making dami puppets, 3) dami puppet animation making. c. Determine evaluation instruments. The evaluation carried out was an evaluation of puppets and children's storytelling skills. Phase IV Initial Field Testing After the dami puppet media for grade IV elementary school has been formed, it is then assessed by experts based on the format of the assessment item, using the score score assessment, suggestion column, and suggestions for improvement materials. Determination of experts in evaluating development products based on the contents of the assessment format, namely aspects of media feasibility, and aspects of presentation. This test is done. While this initial field test was conducted on grade 4 students with 10 students. Stage V Local Wisdom-based Puppet Revision Revisions were made based on advice from the supervisor at the time of the field test. Based on the results of these revisions can then be made back dami puppet for fourth grade students in elementary school. Stage VI Test Product Use After the revision of wayang dami was carried out based on the judgment of the experts, it was then tested on the main field. The subjects were grade IV students of SDN Sukorejo and SDN 
Randuagung, totaling 45 students. A trial to find out the feasibility of wayang dami that has been developed is related to the development of the media of speaking skills, especially storytelling for fourth grade students. Then, it is seen the effectiveness of the use of wayang dami through student learning outcomes through storytelling practice. Stage VII Revision of Field Test Results After being tested, the dami wayang media was subsequently revised based on limited trials in the field, revisions were made to correct the deficiencies contained in the forms of dami wayang, then a prototype of dami wayang media was developed in speaking skills, especially storytelling for elementary school high school students.

Then this study will use class 4 SDN Sukorejo as an experimental class, and class 4 SDN Randuagung as a control class. Experimental research designs can be seen in the following table.

Table 3.1 Research Design

\begin{tabular}{llll}
\hline Class/Group & Pretest & Treatment & Posttest \\
\hline Control & $\mathrm{O}_{1}$ & $\mathrm{X}_{1}$ & $\mathrm{O}_{2}$ \\
Exsperiment & $\mathrm{O}_{3}$ & $\mathrm{X}_{2}$ & $\mathrm{O}_{4}$ \\
\hline
\end{tabular}

Information:

$\mathrm{X} 1$ : Control Class without the use of wayang dami media based on local wisdom Rembang

$\mathrm{X} 2$ : The treatment given to the experimental group is storytelling learning using dami puppet media based on local wisdom of Rembang

O1: The results of the pretest performance of the students of the control class's story telling skills

O2: The results of the posttest's performance telling skills of the control class students

O3: The results of the pretest performance of students' storytelling skills in the experimental class

O4: The results of the post test performance of the storytelling skills of the experimental class students

\subsection{Data Sources and types}

Data sources in this study were students. The explanation is as follows:

a. The population of this research is the 4 th grade students in foster clusters in Sumber District of Rembang Regency in the academic year 2019/2020.

b. The test subjects in this research development are class IV SDN Sukorejo with 23 students as experimental class and class IV Randuagung SDN with 25 students as control class. The research on wayang dami media development in speaking skills, especially storytelling for grade IV elementary school, was conducted in semester 1 of the 2019/2020 school year at SDN Sukorejo, Sumber District, Rembang Regency, Central Java.

\section{Types of Data}

The type of data collected from this study is derived from needs analysis, validity data, acceptance data and effectiveness data. First, the data analysis needs of students and teachers. Secondly, data on the feasibility of dami wayang media is obtained from the results of expert validation by providing input for the improvement of dami wayang media before being tested. Third, data on the acceptance of wayang dami media is obtained from the analysis of teacher responses and the results of students' supervised interviews, and data on the effectiveness of wayang dami media are obtained from the results of improved reading skills and learning outcomes that show more than $75 \%$ of students are completed individually with KKM 75 
From a number of types of data above, it can be proven that the results of the development of puppet dami media based on local wisdom of speaking skills, especially storytelling for grade IV elementary school students, are appropriate to use.

\subsection{Data Collecton Technique}

Data collection techniques that researchers use are data collection techniques:

a. Qualitative

1) Observation of learning

2) Observation of media needs

3) Interview

b. Quantitative

1) Product validation guidelines

2) Performance evaluation tells the story

\subsection{Research Instrument}

Research instruments that researchers use include:

1) Observation guide to learning to tell stories in high class. This observation guide sheet is used when the initial conditions of learning to tell stories in the experimental class have not used the puppet media dami based on local wisdom Rembang. Then also used in the experimental class after learning to use dami puppet media, and in the control class. This observation sheet is used to find out how the storytelling learning process that occurs in the classroom. There are 5 aspects observed. Among other learning materials to tell stories, teaching techniques to tell stories, the use of media in encouraging story telling, student enthusiasm, and the stories used.

2) Guidelines for observing the need for instructional media for storytelling guidelines based on local wisdom of Apex to students

This observation guide is used to find out how much students' needs for learning media tell stories. Aspects of observation include the enthusiasm of students, the curiosity of students, the interest in using puppets based on local wisdom of Rembang, and the ability of students to use puppets based on local wisdom of Rembang.

3) Guidelines for observing the need for instructional media learning guidelines based on local wisdom of Apex to teachers.

These observation guidelines are used to determine the teacher's need for storytelling split media. The aspect observed in this observation is the teacher's response to the puppet-based Dami local wisdom Rembang, the teacher explains the puppet-based Dami local wisdom Rembang, the teacher uses the puppet-based dami local wisdom Rembang, the teacher creates a pleasant atmosphere in learning to tell using the puppet-based local wisdom Rembang

4) Guidelines for interviewing students

This interview guide is used to see students' answers directly to the needs of wayang dami based on Rembang's local wisdom in storytelling learning. The interview used was a structured interview with 3 questions that were prepared by the researcher.

5) Guidelines for interviewing teachers. This interview guide is used to see the teacher's answers directly to the need for wayang dami based on Rembang's local wisdom in storytelling learning. The interview used was a structured interview with 4 questions that were prepared by the researcher.

6) Product validation guidelines 
Product validation guidelines contain aspects that must be fulfilled by learning media and their scoring. The validated aspect is the physical media of the dami puppet media and the form of dami wayang based presentation of the local wisdom of Rembang in storytelling learning.

7) Performance evaluation tells the story

The type of test that researchers use is a performance test to measure the extent of the ability to retell. The aspects assessed during the performance are the story line, the smoothness of storytelling, pauses and intonation, and the expression of students in storytelling.

\subsection{Data Validity Test}

Need analysis

Data validity test is done by determining the characteristics of needs according to the perception of teachers and students by determining the percentage of answers to each item item. The formula is as follows:

$$
\% f=\frac{f}{N} \times 100
$$

Information:

$\% f=$ percentage of respondent's will

$f=$ frequency of answers from respondents

$\mathrm{N}=$ number of respondents

This means that in each item the respondent's answer frequency will be counted. The highest frequency is taken into consideration as a description of the will of the respondent in each question item, so that in the development of prototypes dami media based on local wisdom Rembang must pay attention to these results.

Data Analysis of Dami Puppet Media Validity Test

The next data is the results of the validity evaluation of wayang dami based on local wisdom of Rembang. This assessment is obtained by presenting a prototype of teaching materials to experts with completed assessment sheets that have been provided. The results of the assessment obtained will then be analyzed on a percentage based on the score obtained on each item of assessment. How, after knowing the value of each statement, the value is accumulated and the average score is sought.

The steps in determining media eligibility are as follows:

Recapitulate data on media feasibility assessment in a table covering aspects, indicators, and values for each validator.

Determine the average value of the validation results of all validators for each indicator using the following formula:

Information;

$$
N A=\frac{\sum S R}{\sum S I} \times 100 \%
$$

NA: Final Score

SR: Validator Score

SI: Ideal Score (Maximum Score x number of items) 
Scores and categories of assessment by media experts can be seen in the table below.

Table 3.8 Media Expert Test Assessment Scores

\begin{tabular}{cc}
\hline Number of Scores Obtained & the Teaching Material Rating \\
& Category \\
\hline $0 \leq \mathrm{x} \leq 25$ & Less \\
$25 \leq \mathrm{x} \leq 50$ & Enough \\
$50 \leq \mathrm{x} \leq 75$ & Good \\
$75 \leq \mathrm{x} \leq 100$ & Very Good \\
\hline
\end{tabular}

\subsection{Data Analysis}

The next data analysis is the effectiveness of local puppet-based media based on local wisdom for high-class students can be seen from:

a. Analysis of the results of the performance assessment of storytelling skills

Performance evaluation sheet storytelling skills then in the percentage of completeness of the minimum post-test more than $75 \%$ of students complete with KKM 70. Analysis of data effectiveness of the puppet media based on local wisdom for grade IV elementary school students is done using the processing results of storytelling skills obtained in research. To find out the level of effectiveness of the puppet media dami to the ability of students, it can be seen using a Score Test (N-gain) with the following formula:

$$
\mathrm{g}=\frac{\text { skor post test-skor pretest }}{\text { skor ideal-skor pretes }}
$$

b. Comparative analysis of the average performance results and the percentage of storytelling skills was also carried out in the control class and the experimental class.

Then the researcher will compare the average results and the completeness of the performance of story telling skills between the control class and the experimental class with the following formula:

Information :

$$
t=\frac{X_{1}-X_{2}}{\sqrt{\frac{s_{1}^{2}}{n_{1}}+\frac{s_{2}^{2}}{n_{2}}-2 r\left(\frac{s_{1}}{\sqrt{n_{1}}}\right)\left(\frac{s_{2}}{\sqrt{n_{2}}}\right)}}
$$

$\mathrm{t}=\mathrm{t}$ arithmetic which is further consulted with $\mathrm{t}$ table

$\mathrm{X} \_1$ = sample average 1

$\mathrm{X} \_2$ = sample average 2

$\mathrm{s} \_1=$ sample standard deviation 1

s_2 = standard sample deviation 2

s_ $1 \wedge 2=$ sample variant 1

s_ $2^{\wedge} 2=$ sample variant 2

$\mathrm{r}=$ correlation 


\section{References}

[1] Arsjad, Maidar dam Mukti, U.S. 1993. Pembinaan Kemampuan Berbicara Bahasa Indonesia. Jakarta: Erlangga.

[2] Keraf, A.S., 2002. Etika Lingkungan. Jakarta: Penerbit Buku Kompas.

[3] Rif'an, Ali.2010.Buku Pintar Wayang.Jogjakarta:Garaiilmu

[4] Sadiman, Arief S., dkk.2014.Media Penddikan:Pengertian, Pengembangan, dan Pemanfaatannya.Jakart:Rajawali Pers.

[5] Sartini, 2004. Menggali Kearifan Lokal Nusantara: Sebuah Kajian Filsafati. Yogyakarta: UGM

[6] Tarigan, H.G.1981.Berbicara.Bandung:Angkasa.Tarigan, H.G. (1981). Berbicara

[7] Tarigan, Djago dan Tarigan, H.G.1990.Teknik Pengajaran Keterampilan Berbahasa. Bandung:Angkasa.

[8] Tarigan, Henry Guntur. 1993. Berbicara sebagai suatu keterampilan berbahasa. Bandung: Angkasa.

[9] Tjahjono, P.E., Suminar, P., Aminuddin, A. dan Hakim, K., 2000. Pola Pelestarian Keanekaragaman Hayati Berdasarkan Kearifan Lokal Masyarakat Sekitar Kawasan TNKS di Propinsi Bengkulu.Prosiding Hasil Penelitian SRG TNKS. Hal 164-173. Kehati Jakarta.

[10] Dwistyawan dan Setiawan. 2017.Pengenalan Tokoh Wayang dalam Cerita Ramayana dengan Menggunakan Media Board Game untuk Masyarakat. http://puslit2.petra.ac.id/ejournal/index.php/dkv/article/view/19196. Diunduh tanggal 10 Juni 2019.

[11] Faturrohman, dkk. 2014.Film Animasi Sebagai Media Pembelajaran Terpadu Untuk Memacu Keaksaraan Multibahasa Pada Siswa Sekolah Dasar. https://jurnal.umk.ac.id/index.php/RE/article/view/4. Diunduh tanggal 10 Juni $\underline{2019}$

[12] Hotibin, 2013.Sekilas tentang Kearifan Lokal Masyarakat. http://kangebink.blogspot.com/2013/10/sekilas-tentang-kearifan-lokal.html. Diunduh tanggal 10 Juni 2019

[13] Kristanti, Anastasia.2015.Pengertian Pendidikan menurut KH Dewantara dan Driyarkara. https://anastasiakristanti.blogs.uny.ac.id/2015/09/2017. Diunduh tanggal 10 Juni 2019

[14] Utaminingsih, 2019.Pengembangan Media Scrap Book Tema 4 Berbagai Pekerjaan $\begin{array}{lllll}\text { Subtema } & 3 & \text { Pekerjaan Tuaku. }\end{array}$ https://ejournal.undiksha.ac.id/index.php/JJL/article/viewFile/17378/10449 Diunduh tanggal 10 Juni 2019

[15] Salamah, Evi Rizki.2012.Penggunaan Media Wayang Pada Pembelajaran IPS Materi Tokoh Tokoh Kemerdekaan Indonesia Untuk Meningkatkan Hasil Belajar Siswa Kelas V Sekolah Dasar. http://ejournal.upi.edu/index.php/MetodikDidaktik/article/view/7684/4944. Diunduh 20 Juni 2019.

[16] Zafira dan Prima.2017.Pengembangan Media Wayang Tematik Pada Tema Indahnya Negeriku Sebagai Pendukung Scientific Approach Kelas IV Sekolah Dasar. https://jurnal.umk.ac.id/index.php/RE/article/view/1778/1144. Diunduh tanggal 10 Juni $\underline{2019}$ 